\title{
Clinical Value of Core Lenght in Saturation Prostate Biopsy
}

\author{
Kor Uzunluğunun Saturasyon Prostat Biyopsisindeki Klinik Önemi
}

\author{
(D) Cem Yücel11, (D) Salih Budak² \\ 1 University of Health Sciences, Izmir Tepecik Training and Research Hospital, Clinic of Urology, İzmir, Turkiye \\ 2Sakarya University Training and Research Hospital, Clinic of Urology, Sakarya, Turkiye
}

\section{What's known on the subject? and What does the study add?}

To our best knowledge, our study is the first to evaluate the clinical value of total core length in saturation prostate biyopsy. Mean and total core length may not have significant impact on prostate cancer detection in patients receiving saturation prostate biopsy.

\begin{abstract}
Objective: To investigate the effect of core length on cancer detection in saturation prostate biopsy. We hypothesized that increasing mean and total core length in saturation prostate biopsy may allow more tissue sampling, thus, may increase the prostate cancer detection rate.

Materials and Methods: We retrospectively analyzed medical records of 145 patients who underwent 24-core transrectal ultrasound-guided saturation biopsy at our institution. We evaluated the clinopathological factors, including age, prostate specific antigen (PSA), prostate volume, mean core length and the total biopsy core length. The patients were divided into 3 groups according to their total biopsy core length; group 1: $<20$ $\mathrm{cm}$, group 2: 20-30 cm and group 3: $>30 \mathrm{~cm}$. These groups were compared according to age, PSA value, prostate volume and cancer detection rate. Results: The mean age, core length and total core length were $62.4 \pm 7.0$ years, $10.91 \pm 1.8 \mathrm{~mm}$, and $26.2 \pm 4.7 \mathrm{~cm}$, respectively. The overall cancer detection rate was 33.8\%. There was no statistically significant difference in mean core length and total core length between patients diagnosed with prostate cancer and those without it. The cancer detection rates in group 1, 2 and 3 were 25\%, 37.4\% and 23.1\%, respectively. When these 3 groups were compared with each other, group 2 had a statistically significantly higher cancer detection rate relative to group 1 ( $p=0.001$ ). Multivariate analysis showed no statistically difference in cancer detection rate between the groups $(p=0.302)$.

Conclusion: Mean and total core length may not have any significant effect on prostate cancer detection in patients undergoing saturation prostate biopsy.
\end{abstract}

Keywords: Saturation biopsy, Core length, Prostate cancer

Öz

Amaç: Kor uzunluğunun saturasyon prostat biyopsisinde kanser saptamaya etkisini araştırmaktır. Hipotezimiz, ortalama ve toplam kor uzunluğunun artırılması ile daha fazla doku örneği sağlıyacağı için prostat kanseri saptama oranında artış gözleneceğidir.

Gereç ve Yöntem: Kurumumuzda 24 kadran transrektal prostat biyopsisi olan 145 hastanın medikal verilerini retrospektif olarak analiz ettik. Hasta yaşı, prostat spesifik antijen (PSA) değeri, prostat hacmi, ortalama kor uzunluğu, toplam kor uzunluğunu değerlendirdik. Hastalar toplam biyopsi kor uzunluğuna göre üç gruba ayrıldı. Grup 1: $<20 \mathrm{~cm}$, grup 2: 20-30 cm ve grup 3: $>30 \mathrm{~cm}$. Bu gruplar yaş, PSA değeri, prostat hacmi ve kanser saptama oranlarına göre karşılaştırıldı.

Bulgular: Ortalama yaş, kor uzunluğu ve toplam kor uzunluğu sırasıyla $62,4 \pm 7,0$ yıl, 10,91 $\pm 1,8 \mathrm{~mm}, 26,2 \pm 4,7 \mathrm{~cm}$ idi. Toplam kanser saptama oranı $\% 33,8$ 'di. Prostat kanseri olan ve olmayan hasta grupları arasında ortalama kor uzunluğu ve toplam kor uzunluğu açısından istatistiksel anlamlı farklılık yoktu. Grup 1, 2 ve 3'ün kanser saptama oranları sırasıyla \%25, \%37,4 ve \%23,1'di. Üç grup birbirleriyle karşılaştırıldığında grup 2'de kanser saptama oranı grup 1'e göre istatistiksel anlamlı yüksekti $(p=0,001)$. Çok değişkenli analiz ile gruplar karşılaştırıldığında gruplar arasında kanser saptama oranı açısından istatistiksel anlamlı farklılık gözlenmedi $(p=0,302)$.

Sonuç: Ortalama ve toplam kor uzunluğunun prostat saturasyon biyopsisi olan hastalarda prostat kanseri saptamaya anlamlı bir etkisi yoktur. Anahtar Kelimeler: Saturasyon biyopsisi, Kor uzunluğu, Prostat kanseri

Correspondence: Cem Yücel MD, University of Health Sciences, İzmir Tepecik Training and Research Hospital, Clinic of Urology, İzmir, Turkiye E-mail: meclecuy@hotmail.com ORCID-ID: orcid.org/0000-0003-0838-9199

Received: 19.11.2017 Accepted: 26.02.2018

Cite this article as: Yücel C, Budak S. Clinical Value of Core Lenght in Saturation Prostate Biopsy. J Urol Surg 2018;5(2):93-97.

बCopyright 2018 by the Association of Urological Surgery / Journal of Urological Surgery published by Galenos Publishing House. 


\section{Introduction}

Prostate cancer ( $\mathrm{PCa}$ ) is the most common cancer among men (1). PCa is generally suspected in the presence of abnormal digital rectal examination (DRE) and/or elevated prostate specific antigen (PSA) levels. The definitive diagnosis of PCa depends on histopathological confirmation of carcinoma in prostate biopsy cores (2). The PCa detection rate has been reported to vary between $20 \%$ and $25 \%$ in the initial biopsy (3). Saturation biopsy involves extensive sampling of the prostate. Saturation techniques do not provide increased cancer detection when used for initial biopsy, but may provide increased sensitivity when repeat biopsies are performed (4). It has been reported in a meta-analysis that the saturation prostate biopsy technique has provided an important advantage in the diagnosis of $\mathrm{PCa}$ (5). The PCa detection rate is $30-43 \%$ in saturation biopsy and depends on the number of cores sampled during the biopsy; therefore, it may be considered that the amount of prostate tissue obtained in a biopsy may increase PCa detection rate $(6,7)$. We hypothesized that increasing the mean and total core length in saturation prostate biopsy may provide more tissue sampling, thus, this may increase the PCa detection rate.

\section{Materials and Methods}

Medical records of 1240 patients, who underwent prostate biopsy in our hospital between June 2013 and August 2016, were retrospectively evaluated. Among these, 145 patients aged 40-80 years, who had a PSA value of less than $30 \mathrm{ng} / \mathrm{mL}$ and underwent a second transrectal ultrasound (TRUS)-guided prostate biopsy, were included in the study. These patients had undergone a second prostate biopsy due to elevated PSA values over $4 \mathrm{ng} / \mathrm{mL}$. All second biopsies were performed using the 24-core saturation biopsy scheme. Patients were excluded if at least one biopsy core did not include prostate tissue (containing only rectal mucosa, blood, or periprostatic tissue). Patients were also excluded if they had a prior diagnosis of $\mathrm{PCa}$, abnormal DRE findings, or previous anti-androgen or radiation therapy. Cores with the diagnoses of atypical small acinar proliferation and prostatic intraepithelial neoplasia were classified into benign category.

After having obtained informed consents from the patients, all biopsies were carried out transrectally with ultrasonography guidance using a $25 \mathrm{~cm}$ 18-gauge, side-notch cutting (Tru-cut) needle. The biopsies were performed using periprostatic nerve blockage with the patient in the lateral decubitus position. All zones of the prostate were sampled. Each sample was carefully pulled away from the needle and core quality was macroscopically evaluated by the urologist. In case of a poor core quality, another biopsy was obtained from the same site of the prostate. Each sample was transferred to a container including 10\% formaldehyde for histopathological examination.
Each prostate biopsy core was measured by the pathologist and we summed up these measurements and achieved the total biopsy core length.

After histopathological assessment, we evaluated the clinopathological factors, including age, PSA, prostate volume, mean core length and total biopsy core length. The patients included in the study were assigned into 3 groups according to their length of total biopsy cores. Group 1: $<20 \mathrm{~cm}$, group 2: 20-30 cm and group 3: $>30 \mathrm{~cm}$. These groups were compared according to age, PSA value, prostate volume and cancer detection rate.

\section{Statistical Analysis}

Compliance of the variables to the normal distribution was evaluated using the Shapiro-Wilk test. The descriptive statistics for normally distributed variables and the categorical variables were expressed as mean \pm standard deviation and percentages $(\%)$. Student's t-test and chi-square test were used for the inter-group analysis of the continuous variables. More than two independent averages were compared with the ANOVA test, Kruskal-Wallis test and the post-hoc Dunn's test. The data analysis was carried out using the Statistical Package for the Social Science (SPSS Inc, Chicago, Illinois, USA) version 22.0 and a $p$ value of $<0.05$ was considered statistically significant.

\section{Results}

The biopsy records of 1240 patients were evaluated. Among these 1240 patients, saturation biopsy (24-core) was performed in only 145 patients.

The mean age of the patients was $62.4 \pm 7.0$ years, the mean total PSA value was $10.5 \pm 7.5 \mathrm{ng} / \mathrm{mL}$, the mean total core length was $26.2 \pm 4.7 \mathrm{~cm}$, the mean core length was $10.91 \pm 1.8 \mathrm{~mm}$, the mean prostate volume was $52.1 \pm 29.7 \mathrm{~mL}$ and the overall cancer detection rate was $33.8 \%$ (Table 1 ).

Pathological investigation revealed PCa in 49 of the 145 patients $(33.8 \%)$, and a benign result in the remaining 96 . The mean total core length was $25.9 \pm 3.9 \mathrm{~cm}$ in patients who had cancer and $26.4 \pm 5.1$ in patients who had no cancer. The difference was not statistically significant $(p=0.617)$. The mean core length in the cancer and benign group was $10.79 \pm 1.7 \mathrm{~mm}$ and $10.95 \pm 1.8$ $\mathrm{mm}$, respectively. This difference was not statistically significant $(p=0.815)$. The clinical variables of the cancer and the benign groups are presented in Table 1.

The patients included in the study were assigned into 3 groups according to the length of the total biopsy cores; group 1: $<20$ $\mathrm{cm}$, group 2: $20-30 \mathrm{~cm}$ and group $3:>30 \mathrm{~cm}$. The number of patients in group 1, 2 and 3 was 22, 88 and 35, respectively. The cancer detection rate in group 1, 2 and 3 was $25 \%, 37.4 \%$ and 
23.1\%, respectively (Table 2). Comparison between the groups revealed a significantly higher rate of cancer in group 2 than in group 1 ( $p=0.001)$. However, when the cut-off value for the total core length was accepted as $20 \mathrm{~cm}$, it was concluded that this core length was not sufficiently sensitive or specific for the diagnosis of PCa ( $p=0.465$, odd ratio $=1.002$, 95\% confidence interval $=0.369-0.562$ ) (Figure 1). After comparing the three

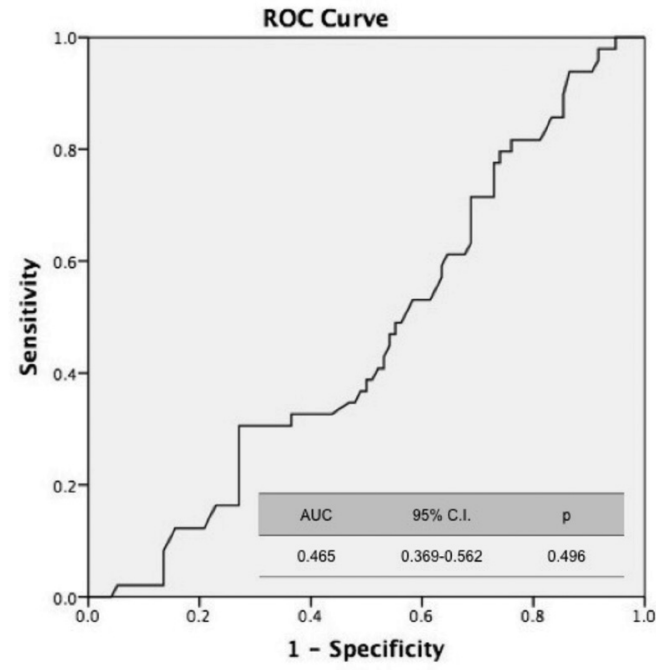

Figure 1. The receiver operating characteristic curve for total core lenght for diagnosing prostate cancer

Table 1. Clinical variables of cancer group and no cancer group

\begin{tabular}{lllll}
\hline & Entire study & Cancer & No cancer & $\begin{array}{l}\mathbf{p} \\
\text { value }\end{array}$ \\
\hline Age (years) & $62.4 \pm 7.0$ & $64.7 \pm 6.7$ & $61.3 \pm 6.9$ & 0.006 \\
PSA (ng/mL) & $10.5 \pm 7.5$ & $9.1 \pm 6.8$ & $11.2 \pm 7.8$ & 0.072 \\
$\begin{array}{l}\text { Prostate volume } \\
(\mathrm{mL})\end{array}$ & $52.1 \pm 29.7$ & $52.1 \pm 24.7$ & $57.2 \pm 30.8$ & 0.161 \\
$\begin{array}{l}\text { Mean core } \\
\text { lenght (mm) }\end{array}$ & $10.91 \pm 1.8$ & $10.79 \pm 1.7$ & $10.95 \pm 1.8$ & 0.815 \\
$\begin{array}{l}\text { Total core } \\
\text { lenght (cm) }\end{array}$ & $26.2 \pm 4.7$ & $25.9 \pm 3.9$ & $26.4 \pm 5.1$ & 0.617 \\
\hline PSA: Prostate specific antigen & & & \\
\hline
\end{tabular}

Table 2. Comparison of patients according to their total biopsy core lengths

\begin{tabular}{|c|c|c|c|c|}
\hline & Group 1 & Group 2 & Group 3 & $\begin{array}{l}p \\
\text { value }\end{array}$ \\
\hline & $(<20 \mathrm{~cm})$ & $(20-30 \mathrm{~cm})$ & $(30<\mathrm{cm})$ & \\
\hline Age (years) & $63.0 \pm 8.0$ & $62.9 \pm 6.4$ & $60.1 \pm 8.3$ & 0.173 \\
\hline PSA (ng/mL) & $11.6 \pm 6.1$ & $10.3 \pm 8.2$ & $10.6 \pm 4.8$ & 0.176 \\
\hline Prostate volume (mL) & $53.2 \pm 31.3$ & $50.1 \pm 29.0$ & $50.3 \pm 29.2$ & 0.318 \\
\hline $\begin{array}{l}\text { Cancer detection } \\
\text { rate }(\%)\end{array}$ & 25.0 & 37.4 & 23.1 & 0.302 \\
\hline
\end{tabular}

groups with the multivariate analysis, there was no statistically significant difference in the cancer detection rate between the groups $(p=0.302)$. We performed multivariate analysis in order to identify if any cut-off value for total core length was predictive for the PCa diagnosis and we could not detect any cut-off value.

When the groups were compared with each other, there was no statistically significantly difference in mean age, total PSA value and prostate volume (Table 2).

\section{Discussion}

In this study, we found that mean core length and total core length in saturation prostate biopsy were not correlated with PCa detection rate. Although we could not confirm our hypothesis, the results of our study will contribute to the literature regarding the importance of core lengths obtained in prostate biopsy.

Despite efforts made to identify new serum and biological markers and refinement of imaging modalities for the diagnosis of PCa, prostate biopsy performed with the guidance of TRUS is still the most important diagnostic method (8). In order to increase the cancer detection rate of prostate biopsy, various schemes have been applied in time such as sextant biopsy, extended biopsy and saturation biopsy (9). Treatment of patients, who are diagnosed not to have cancer in the first prostate biopsy despite persistently elevated levels of PSA, is a common problem for the urologist. Recently, various investigators have demonstrated that a higher diagnostic rate could be achieved via the saturation biopsy technique, which aims at increasing the number of samples obtained and to make sampling from multiple sites of the prostate (10). Borboroglu et al. (11) used an extensive saturation technique to obtain an average of 22.5 cores/patient, and achieved a cancer detection rate of $30 \%$. In a study by Stewart et al. (12), a different scheme of saturation biopsy was used, and a cancer detection rate of 34\% was achieved with a larger sample size. Walz et al. (6) used the 24core saturation biopsy scheme and observed a cancer detection rate of $41 \%$. In our institution, we prefer the 24-core saturation biopsy scheme for a second prostate biopsy. Consistent with the literature, we found the cancer detection rate of $33.8 \%$ in our study.

Although many studies have been published on the number and localization of the cores in the literature, very few have investigated the effect of core length as an indicator of the quality of prostate biopsy (13). This may be affected by many factors, including the length of the core obtained in a biopsy, the biopsy technique performed by the urologist, the diameter of the biopsy needle, the rigidity of the site the sample obtained, and the method of sample collection (14). Although there are studies 
that have revealed that a greater core length increased the rates of PCa diagnosis, there have also been studies suggesting that the diagnosis of PCa was not affected by core length (15). A positive correlation was observed between mean core length and PCa detection in a study by Iczkowski et al. (16) conducted on patients who underwent sextant prostate biopsy, however, this outcome was significant for biopsies obtained from the apex only. According to the literature, the sextant prostate biopsy scheme is not currently recommended. Contrary to Iczkowski et al. (16), we determined that there was no correlation between mean core length and $\mathrm{PCa}$ detection rate.

In a single-center study by Öbek et al. (17) evaluating the medical data of 245 patients who underwent prostate biopsy via the extended sextant 12-18 cores biopsy scheme, all biopsies were performed by the same urologist and nurse, and the same biopsy gun was used in all biopsies. They found a mean core length of $12.3 \pm 2.6 \mathrm{~mm}$ in patients with cancer, and that of $11.4 \pm 2.4 \mathrm{~mm}$ in those with benign pathological results. The difference was determined to be statistically significant (17). The mean core length detected by these authors was longer than our mean core length. In our study, the biopsy sampling was performed by different urologists, thus, the homogenization of the data obtained in our study was limited. Ficarra et al. (18) reviewed the medical data of 509 prostate biopsies obtained through the transperineal approach, and reported that the mean length of cores diagnosed with PCa was similar to those with benign pathological results. They demonstrated that the transperineal prostate biopsy technique provided better and more sensitive sampling compared to the prostate apex, midgland and the base (18). In contrast to this study, we use the transrectal prostate biopsy technique in our clinics, which is easier, cost-effective and provides a better quality.

Lee et al. (14) reported that 3479 patients with a PSA level of $<10$ $\mathrm{ng} / \mathrm{mL}$ were evaluated after multi-core prostate biopsy, and the mean core length for patients with and without cancer was the same $(16.1 \mathrm{~mm})$, and hence, they claimed that PCa detection rate was not affected by the core length. Similar to this study and that by Ficarra et al. (18), we did not observe a correlation between mean core length and the cancer detection rate in our study.

To the best of our knowledge, our study is the first to investigate the importance of total core length in prostate biopsy, in the literature. Our results did not support our hypothesis. We found no relationship between total core length and PCa detection rate in saturation biopsy. We thought, as reported by Lee et al. (14), that the outcomes of our study may be explained by a hypothesis similar to that suggested as 'saturation' in physical chemistry. Accordingly, if the total core length in prostate biopsies has reached a plateau for the diagnosis of $\mathrm{PCa}$, longer core lengths obtained would no further contribute to the diagnosis of $\mathrm{PCa}$.

\section{Study Limitations}

Our study has some limitations. The first limitation is that our study had a retrospective design. We did not separately assess the cores with and without cancer. The second limitation was not assessing the whole prostate gland after radical prostatectomy. Another limitation of our study was its small sample size. Further multi-center studies with larger sample sizes will provide more accurate insight into the subject.

\section{Conclusion}

Mean and total core lengths may not have significant effect on $\mathrm{PCa}$ detection in patients undergoing saturation prostate biopsy. The outcomes obtained in our study will provide information regarding the importance of core lengths obtained in a prostate biopsy. Multi-center, prospective studies with larger sample sizes will provide a more accurate picture for the clinical significance of the core length in prostate biopsy.

\section{Ethics}

Ethics Committee Approval: Ethics committee approval was not applied because of retrospective design.

Informed Consent: Consent form was filled out by all participants.

Peer-review: Externally peer-reviewed.

\section{Authorship Contributions}

Surgical and Medical Practices: C.Y., Concept: C.Y., Design: C.Y., Data Collection or Processing: S. B., Analysis or Interpretation: C.Y., Literature Search: S.B., Writing: C.Y.

Conflict of Interest: No conflict of interest was declared by the authors.

Financial Disclosure: The authors declared that this study received no financial support.

\section{References}

1. Guichard $G$, Larre $S$, Gallina $A$, Lazar A, Faucon $H$, Chemama $S$, Allory $Y$, Patard JJ, Vordos D, Hoznek A, Yiou R, Solomon L, Abbou CC, de la Taille A. Extended 21-sample needle biopsy protocol for diagnosis of prostate cancer in 1000 consecutive patients. Eur Urol 2007;52:430-435.

2. Heidenreich A, Bastian PJ, Bellmunt J, Bolla M, Joniau $S$, van der Kwast $T$, Mason M, Matveev V, Wiegel T, Zattoni F, Mottet N; European Association of Urology. EAU guidelines on prostate cancer. Part 1: screening, diagnosis, and local treatment with curative intent-update 2013. Eur Urol 2014;65:124137.

3. Djavan B, Ravery V, Zlotta A, Dobronski P, Dobrovits M, Fakhari M, Seitz C, Susani M, Borkowski A, Boccon-Gibod L, Schulman CC, Marberger M. Prospective evaluation of prostate cancer detected on biopsies 1,2,3, and 4: When should we stop? J Urol 2001;166:1679-1683. 
4. Durkan GC, Sheikh N, Johnson P, Hildreth AJ, Greene DR. Improving prostate cancer detection with an extended-core transrectal ultrasonographyguided prostate biopsy protocol. BJU Int 2002;89:33-39.

5. Jiang $X$, Zhu S, Feng G, Zhang Z, Li C, Li H, Wang C, Xu Y. Is an initial saturation prostate biopsy scheme better than an extended scheme for detection of prostate cancer? A systematic review and meta-analysis. Eur Urol 2013;63:1031-1039.

6. Walz J, Graefen M, Chun FK, Erbersdobler A, Haese A, Steuber T, Schlomm $\mathrm{T}$, Huland $\mathrm{H}$, Karakiewicz PI. High incidence of prostate cancer detected by saturation biopsy after previous negative biopsy series. Eur Urol 2006;50:498-505.

7. Irani J, Blanchet $\mathrm{P}$, Salomon $\mathrm{L}$, Coloby $\mathrm{P}$, Hubert J, Malavaud B, Mottet N. Is an extended 20-core prostate biopsy protocol more efficient than the standard 12-core? A randomized multicenter trial. J Urol 2013;190:77-83.

8. Chun FK, Epstein Jl, Ficarra V, Freedland SJ, Montironi R, Montorsi F, Shariat SF, Schröder FH, Scattoni, V. Optimizing performance and interpretation of prostate biopsy: a critical analysis of the literature. Eur Urol 2010;58:851-864.

9. Ceylan C, Doluoglu OG, Aglamis E, Baytok O. Comparison of 8, 10, 12, 16, 20 cores prostate biopsies in the determination of prostate cancer and the importance of prostate volume. Can Urol Assoc J 2014;8:81-85.

10. Scattoni V, Zlotta A, Montironi R, Schulman C, Rigatti P, Montorsi F. Extended and saturation prostatic biopsy in the diagnosis and characterisation of prostate cancer: a critical analysis of the literature. Eur Urol 2007:52;1309-1322.
11. Borboroglu PG, Comer SW, Riffenburgh RH, Amling CL. Extensive repeat transrectal ultrasound guided prostate biopsy in patients with previous benign sextant biopsies. J Urol 2000;163:158-162.

12. Stewart CS, Leibovich BC, Weaver AL, Lieber MM. Prostate cancer diagnosis using a saturation needle biopsy technique after previous negative sextant biopsies. J Urol 2001;166:86-91.

13. Ergün $M$, İslamoğlu $E$, Yalçınkaya $S$, Tokgöz $H$, Savaş $M$. Does length of prostate biopsy cores have an impact on diagnosis of prostate cancer? Turk J Urol 2016;42:130-133

14. Lee $\mathrm{S}$, Jeong SJ, Hwang SI, Hong SK, Lee HJ, Byun SS, Choe G, Lee SE. Clinical value of core length in contemporary multicore prostate biopsy. PLoS One 2015;10:e0123704.

15. Fiset PO, Aprikian A, Brimo F. Length of prostate biopsy cores: does it impact cancer detection. Can J Urol 2013;20:6848-6853.

16. Iczkowski KA, Casella G, Seppala RJ, Jones GL, Mishler BA, Qian J, Bostwick DG. Needle core length in sextant biopsy influences prostate cancer detection rate. Urology 2002;59:698-703.

17. Öbek $C$, Doğanca $T$, Erdal $S$, Erdoğan $S$, Durak H. Core length in prostate biopsy: size matters. J Urol 2012;187:2051-2055.

18. Ficarra V, Martignoni G, Novella G, Cerruto MA, Galfano A, Novara G, Pea $M$, Artibani W. Needle core length is a quality indicator of systematic transperineal prostate biopsy. Eur Urol 2006;50:266-271. 